\title{
Factors that Affect Spread of Pseudomonas syringae in the Phyllosphere
}

\author{
Christen D. Upper, Susan S. Hirano, Kimberly K. Dodd, and Murray K. Clayton
}

First author: Department of Plant Pathology and Plant Disease Resistance Research Unit, U.S. Department of Agriculture-Agricultural Research Service, University of Wisconsin, Madison 53706; second and third authors: Department of Plant Pathology, University of Wisconsin, Madison 53706; and fourth author: Departments of Plant Pathology and Statistics, University of Wisconsin, Madison 53706. Accepted for publication 23 March 2003.

\begin{abstract}
Upper, C. D., Hirano, S. S., Dodd, K. K., and Clayton, M. K. 2003. Factors that affect spread of Pseudomonas syringae in the phyllosphere. Phytopathology 93:1082-1092.

Successful spread of an organism to a new habitat requires both immigration to and growth on that habitat. Field experiments were conducted to determine the relative roles of dispersal (i.e., immigration) and bacterial multiplication in spread of Pseudomonas syringae pv. syringae in the phyllosphere. To study spread, individual plots consisted of three nested concentric squares with the inner $6 \mathrm{~m}^{2}$ planted to snap beans serving as the sink. Each sink, in turn, was surrounded by a barrier zone, usually $6 \mathrm{~m}$ wide, which was surrounded by a 6-m-wide source area. The source areas were planted with snap bean seeds inoculated with doubly marked strains derived from wild-type $P$. syringae pv. syringae B728a. The treatments were designed to test the effects of the nature and width of the barrier zone and suitability of the habitat in the sinks on spread of $P$. syringae pv. syringae. The marked strains introduced into the source areas at the time of planting were consistently detected in sink areas within a day or two after emergence of bean seedlings in the sources as

assessed by leaf imprinting and dilution plating. The amounts of spread (population sizes of the marked strain in sinks) across barrier zones planted to snap bean (a suitable habitat for growth of $P$. syringae pv. syringae), soybean (not a favorable habitat for $P$. syringae pv. syringae), and bare ground were not significantly different. Thus, the nature of the barrier had no measurable effect on spread. Similarly, spread across bareground barriers $20 \mathrm{~m}$ wide was not significantly different from that across barriers $6 \mathrm{~m}$ wide, indicating that distance on this scale was not a major factor in determining the amount of spread. The suitability of the sink for colonization by $P$. syringae pv. syringae had a measurable effect on spread. Spread to sinks planted to clean seed was greater than that to sinks planted with bean seeds inoculated with a slurry of pulverized brown spot diseased bean leaves, sinks planted 3 weeks before sources, and sinks planted to a snap bean cultivar that does not support large numbers of $P$. syringae pv. syringae. Based of these results, we conclude that the small amount of dispersal that occurred on the scale studied was sufficient to support extensive spread, and suitability of the habitat for multiplication of $P$. syringae pv. syringae strongly influenced the amount of spread.
\end{abstract}

For an organism to spread to a new habitat, it must disperse to that habitat and then multiply on that habitat. If either of these steps does not occur, i.e., the organism does not disperse to the habitat or the organism fails to reproduce in the new habitat, spread to that habitat is not successful. When describing the epidemiology of plant diseases, we often say that a disease has spread when new disease occurs. The occurrence of new disease implies that the pathogen has successfully dispersed to a new habitat, a susceptible host, and that growth on the host has occurred, leading to disease. Much of the classical epidemiology of plant diseases has been developed for diseases in which disease development can be equated to pathogen reproduction (22). The theories developed for such cases often provide excellent models for diseases in which all or nearly all pathogen multiplication occurs in lesions, a process exemplified by numerous fungal diseases.

Many phytopathogenic bacteria multiply quite successfully in association with susceptible tissue without causing lesions (7). Attempts to fit classical epidemiological models to such diseases are often less successful and clearly have less biological relevance. Bacterial brown spot of snap beans (Phaseolus vulgaris L.), caused by Pseudomonas syringae pv. syringae, is an example of a disease in which pathogen multiplication is often independent of disease causation $(14,21)$. In this system, the likelihood of dis-

Corresponding author: C. D. Upper; E-mail address: cdu@plantpath.wisc.edu

Publication no. P-2003-0616-02R

(C) 2003 The American Phytopathological Society ease occurring on a given leaf is a function of pathogen population size on that leaf (21). As pathogen population sizes increase, so does the probability of disease development. When pathogen populations remain small to modest in size, host and pathogen coexist without disease.

Dispersal and multiplication-spread of the pathogen-often occur independently from lesion occurrence. Lesions, on the other hand, occur when extensive pathogen multiplication occurs and population sizes become quite high. Raindrop momentum during intense rain events often triggers onset of extensive multiplication of $P$. syringae pv. syringae (3). Growth of the pathogen, already present on leaves, in response to rains results in population sizes that increase the probability of brown spot disease occurrence. Because pathogen spread requires dispersal to leaves to initiate populations followed by multiplication to increase pathogen population sizes, intense rains increase the amount of spread of $P$. syringae pv. syringae through its effects on pathogen growth.

Plant canopies are unusually open systems. In addition to splash dispersal by rain or irrigation $(1,23)$, movement of phyllosphere bacteria occurs by aerosols generated when leaves are dry and wind speeds are greater than $1 \mathrm{~m} \mathrm{~s}^{-1}(15,16)$. Epiphytic bacteria may also be dispersed by insects $(2,11)$. When leaves of snap bean plants are wet, for example with dew, insects traversing leaf surfaces appear to become passively contaminated with bacteria that may be deposited on other leaves and plants as insects move about $(2,6)$. Farm equipment, workers, and irrigation water are among the many other means by which bacteria may be dispersed (23). Hence, there are a number of ways that bacteria may immigrate to leaf habitats. The relative quantitative importance of the various 
dispersal mechanisms is not known and probably varies with conditions.

From the perspective of plant disease epidemiology, pathogen spread (dispersal plus multiplication) is important in assessing the likelihood of disease outbreaks. For the most part, previous research has focused on one or the other of the two components of spread. The objective of this research was to determine the effects of various factors on spread of $P$. syringae pv. syringae.

\section{MATERIALS AND METHODS}

Experimental design. Field experiments to study spread of $P$. syringae pv. syringae were conducted at the University of Wisconsin Experiment Station near Arlington, Columbia County, WI, during the growing seasons spanning 1994 to 1999. The experiments described in detail here were conducted in 1994 and 1997 to 1999. The standard individual plot design consisted of three nested concentric squares (Fig. 1). The outer $6 \mathrm{~m}$ of each plot served as the "source" and was planted with snap bean seeds inoculated with a derivative of $P$. syringae pv. syringae strain B728a. P. syringae pv. syringae $\mathrm{B} 728 \mathrm{a}$ is a very good colonizer and pathogen of snap bean plants in the field (9). The inner $6 \mathrm{~m}^{2}$ was the "sink" to which spread from the source was measured. The sink was surrounded on all sides by the source to eliminate directional biases (e.g., the effect of wind direction). Placement of the sink in the center of each plot also minimized cross-contamination of sinks from other sources because the nearest source to any given sink was the one surrounding that sink. The space between the source and sink was termed the "barrier." Barriers were $6 \mathrm{~m}$ wide for most treatments. Barriers $20 \mathrm{~m}$ wide were included in some experiments to examine the effect of barrier width on spread. The overall size of each plot was $30 \mathrm{~m}^{2}$ (6-m barrier) or $58 \mathrm{~m}^{2}$ (20-m barrier). The plots were separated from each other by $5 \mathrm{~m}$ (1994) or $6 \mathrm{~m}$ (all other years) of bare ground.

To ensure reliable monitoring of spread of $P$. syringae pv. syringae $\mathrm{B} 728 \mathrm{a}$ from source areas to sinks, we used doubly marked derivatives of the wild-type strain. $P$. syringae pv. syringae $\mathrm{B} 728 \mathrm{a}$ is resistant to rifampicin. In 1994, we used a spontaneous nalidixic acid-resistant derivative of $P$. syringae pv. syringae $\mathrm{B} 728 \mathrm{a}$ (B728aNal). Although B728aNal colonized bean leaves and caused disease in the field, we subsequently found that the derivative is slightly less fit than the wild-type strain B728a (9). In 1997, 1998, and 1999, we replaced B728aNal with either B728aCm (resistant to chloramphenicol) or B728aGm (resistant to gentamycin). The latter doubly marked derivatives were constructed by site-directed insertion of antibiotic resistance marker cassettes in an intergenic region in the genome of the bacterium (9). The derivatives were indistinguishable from $P$. syringae pv. syringae B728a in fitness in the field (9). All three $P$. syringae pv. syringae B728a derivatives are generically referred to as $P$. syringae pv. syringae $\mathrm{B} 728 \mathrm{a}^{*}$ in the remainder of this article.

Treatments. The treatments were designed to examine the effects on spread of the barriers and of the suitability of the habitat in sinks for multiplication of $P$. syringae pv. syringae $\mathrm{B} 728 \mathrm{a}^{*}$ (Table 1). Barrier treatments included comparisons of spread across bare ground, snap beans, and soybeans, all $6 \mathrm{~m}$ wide. The effect of barrier width was examined by comparing spread across 6- and 20-m bare-ground barriers.

Sink areas were altered in several ways to determine the effect of the suitability of the habitat for growth of $P$. syringae pv. syringae on spread of the bacterium. In the first, sinks were planted to either snap bean cv. Eagle or Hystyle or to soybean (cv. Lemke). The cv. Eagle generally supports larger population sizes of $P$. syringae pv. syringae and, therefore, is more susceptible to bacterial brown spot than cv. Hystyle (S. S. Hirano and C. D. Upper, unpublished data). P. syringae pv. syringae grows poorly on soybean and does not cause disease on that crop. Sinks were additionally altered by planting seeds of cv. Eagle or Hystyle that were inoculated with either a slurry of pulverized dried bean leaves containing a mixture of phyllosphere bacteria, including naturally occurring $P$. syringae pv. syringae or with a single mutant (BSAL1) derived from $P$. syringae pv. syringae B728a. BSAL1 carries a mutation in salA (for syringomycin and lesion formation) - a regulatory gene required for brown spot lesion formation and syringomycin production in laboratory assays (13). The BSAL1 mutant is able to colonize bean plants in the field, although less well than the wild-type strain (S. S. Hirano and C. D. Upper, unpublished data). Finally, untreated cv. Eagle or Hystyle seeds were planted 3 weeks prior to planting the sources. Treatments in which sinks were planted with inoculated seeds or planted 3 weeks before the sources were designed to alter resident bacterial communities on sink plants and determine the effects of such altered communities on spread. For both treatments, the aim was to increase the sizes of resident bacterial populations, particularly naturally occurring $P$. syringae pv. syringae. Treatment of sinks with the BSAL1 mutant was intended to determine the effect of precolonization of leaves with a lesion minus mutant of $P$. syringae pv. syringae B728a on spread.

An additional treatment included in the 1994 experiment examined spread of a mutant (NPS3136) derived from P. syringae pv. syringae $\mathrm{B} 728 \mathrm{a}$ that carries a mutation in the global regulatory gene, gacS (for global activator sensor kinase) $(10,13)$. The gac $S$ mutant NPS3136 (gacS::Tn5) is impaired in several phenotypes, including brown spot lesion formation, production of syringomycin, protease, alginate, and homoserine lactone, and a swarming behavior on soft agar media (cf. 8). The purpose of this additional treatment was to determine the effect of bacterial genotype on spread. Because the gacS mutant is able to establish population sizes similar to those of $P$. syringae pv. syringae $\mathrm{B} 728 \mathrm{a}^{*}$ on germinating seeds (5) and is less fit than the wild-type strain only on above-ground plant parts, we expected early immigration of the mutant strain to be similar to $P$. syringae pv. syringae B728a*, but subsequent multiplication of the gacS mutant in the sinks to which it immigrated to be reduced.

In all experiments, the treatments were arranged in a randomized complete block design, with three (1994 and 1997) or four

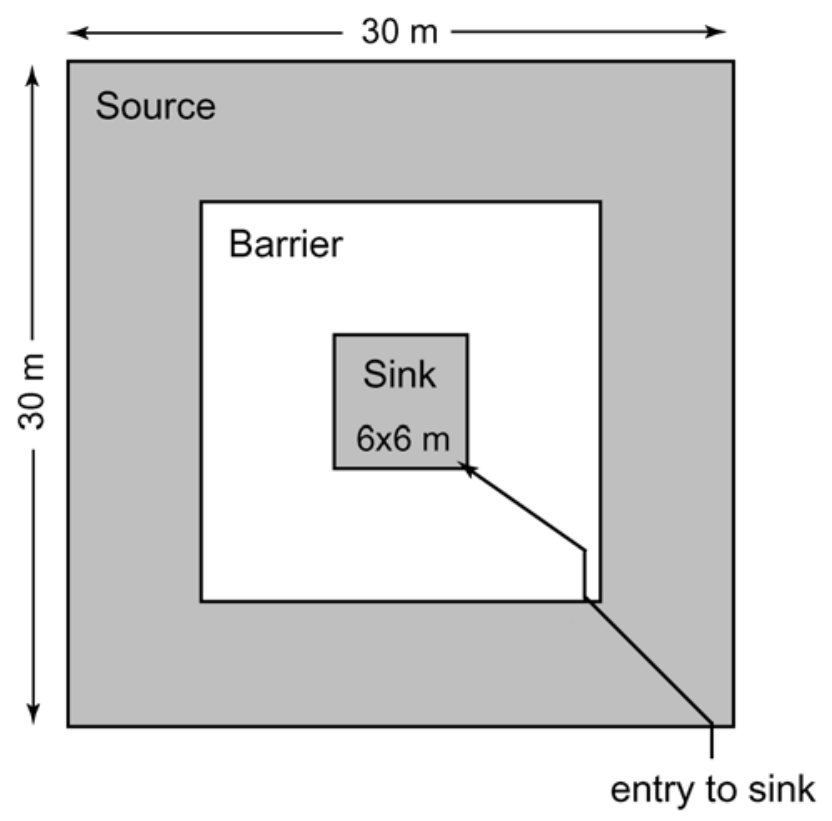

Fig. 1. Plot design. Each plot consisted of three nested squares. The inner square $(6 \times 6 \mathrm{~m})$ was the sink to which spread of Pseudomonas syringae pv. syringae $\mathrm{B} 728 \mathrm{a}^{*}$ from the source (outer $6 \mathrm{~m}$ ) was measured. The source and sink were separated by a $6 \mathrm{~m}$ wide zone termed the barrier. Overall plot dimensions were $30 \times 30 \mathrm{~m}$. Plots were separated by $5 \mathrm{~m}$ bare-ground alleys. Entry to the sink area for sampling purposes was limited to a specific path through the source and barrier as shown. 
(1998 and 1999) blocks. Because each experiment required a rather large area (the largest conducted in 1998 required over 8 ha, with seven treatments and four blocks) and large numbers of samples were collected and processed, it was not logistically feasible to include all possible treatments in all experiments. Hence, test of the treatments and reproducibility of their effects were distributed across several years, as summarized in Table 1 .

Planting and inoculation. Seeds were planted with a tractormounted planter with rows spaced $76 \mathrm{~cm}$ apart. All sinks in an experiment were planted before any of the sources to avoid contamination of the sinks with $P$. syringae pv. syringae B728a* (or the gacS mutant NPS3136 in 1994) during planting. Further, sinks planted to clean seed were planted before those planted with seed inoculated with a mixture of phyllosphere bacteria from dried bean leaves or with the salA mutant BSAL1. In 1994, heavy rains occurred after planting of the sinks which delayed planting of the sources until 2 days later. In 1997, the sources were planted the day after the sinks. In 1998 and 1999, the sinks and sources were planted on the same day. The sources were planted to cv. Eagle in 1994 and 1997 and cv. Labrador in 1998 and 1999 (Asgrow Seed Co., Kalamazoo, MI). The change in cultivar was necessitated by the cessation of commercial production of cv. Eagle seeds.

Bacterial inocula (i.e., P. syringae pv. syringae B728a*, gacS mutant NPS3136, and salA mutant BSAL1) were prepared as described previously (5). Briefly, 2-day-old lawns of bacterial growth were harvested from plates containing King's medium B (KB) (12) supplemented with the appropriate antibiotics. The dense suspensions were diluted to $10^{7} \mathrm{CFU} / \mathrm{ml}$ with water. Seeds planted to the sources were immersed in the diluted inoculum (B728a* or NPS3136) at a ratio of $4 \mathrm{~kg}$ of seeds in 2 liters of inoculum. After $1 \mathrm{~min}$, excess inoculum was drained through a piece of cheesecloth, and the seeds were immediately placed into the hoppers of the planter and planted. For the largest experiment conducted in 1998, roughly 23 batches of seeds were sequentially treated during the 10 to $12 \mathrm{~h}$ required to plant all of the sources in the experiment. Seeds planted to BSAL1-treated sinks were inoculated by treating $1 \mathrm{~kg}$ of $\mathrm{cv}$. Eagle seed in 1 liter of bacterial suspension at $10^{7} \mathrm{CFU} / \mathrm{ml}$.

Seeds for the mixed phyllosphere bacteria-treated sinks were inoculated by immersing $1 \mathrm{~kg}$ of $\mathrm{cv}$. Eagle or Hystyle seeds in 1 liter of water containing dried bean leaf powder $(500 \mathrm{mg})$ mixed with
Talc ( $2 \mathrm{~g})$ as a carrier. The leaf powder was prepared by pulverizing dried brown spot diseased bean leaves of cv. Eagle. After $1 \mathrm{~min}$, the seeds were drained, placed in the hoppers, and planted immediately. All parts of the planter that came in contact with seeds (hoppers, seed plates, plate bases, seed tubes, and packing wheels) were disinfected with $95 \%$ ethanol between seed treatments. Over the course of more than a decade, we have found no clear evidence for any contamination among seed treatments due to failure of disinfestation by this procedure.

Sampling protocol. Because the sinks were located within the sources, the following measures were used to avoid movement of the marked strain from source to sink during sampling or other human activity. Sinks were planted before sources and personnel were not allowed to enter the plots between completion of planting and the first sampling of the plots. A specific diagonal path was designated from the outer corner of a source to the corner of its sink (Fig. 1). Samplers were required to follow this path through the source (and barrier for plots in which the barrier was not bare ground) at all times. At the time of the first sampling, the plants in the sources (and barriers) were sufficiently small that samplers could walk through the path without touching any of these plants. After the first sample was taken in 1994, plants in the designated paths were removed to ensure that samplers would not come in contact with source plants as the plants developed. In the other experiments, the paths were left unplanted. Sampling was initiated in the morning after the dew had evaporated, usually by 0900 h. Samples were never taken when leaves were wet. When possible, different individuals were assigned to sample the sinks and sources. When sufficient numbers of samplers were not available, all sinks were sampled before any of the barriers and sources were sampled. All hands were sterilized with $95 \%$ ethanol before entry into the plots.

The first set of samples was taken from the sinks the day after most of the source plants had emerged. Because source plant emergence did not occur at the same time, a few source plants had been above ground for as long as 2 days at the time the first sample was taken from some of these experiments. The frequency and timing of subsequent samplings varied with experiment but generally followed a schedule in which samples were collected twice weekly for 2 to 3 weeks and then weekly for an additional 2 to 3 weeks. Individual leaflets from the top of the canopy were col-

TABLE 1. Summary of treatments tested ${ }^{\mathrm{a}}$

\begin{tabular}{|c|c|c|c|c|c|}
\hline \multicolumn{2}{|l|}{ Treatment } & \multicolumn{4}{|c|}{ Experiment } \\
\hline Sink & Barrier & 1994 & 1997 & 1998 & 1999 \\
\hline $\begin{array}{l}\text { Control common to all experiments } \\
\text { cv. Eagle (untreated) }\end{array}$ & $6 \mathrm{~m}$ of bare ground ${ }^{\mathrm{b}}$ & + & + & + & + \\
\hline $\begin{array}{l}\text { Barrier treatments } \\
\text { cv. Eagle } \\
\text { cv. Eagle } \\
\text { cv. Eagle }\end{array}$ & $\begin{array}{l}6 \mathrm{~m} \text { of snap beans } \mathrm{s}^{\mathrm{b}} \\
6 \mathrm{~m} \text { of soybeans } \mathrm{b}^{\mathrm{b}} \\
20 \mathrm{~m} \text { of bare ground }\end{array}$ & $\begin{array}{l}+ \\
+ \\
+\end{array}$ & $\begin{array}{l}- \\
\cdots \\
+\end{array}$ & $\begin{array}{l}+ \\
\cdots \\
\cdots\end{array}$ & $\begin{array}{l}+ \\
\ldots \\
\cdots\end{array}$ \\
\hline $\begin{array}{l}\text { Sink treatments } \\
\text { cv. Hystyle (untreated) } \\
\text { Soybean (untreated) } \\
\text { cv. Eagle inoculated with mixed phyllosphere bacteriac } \\
\text { cv. Hystyle inoculated with mixed phyllosphere bacteria }{ }^{c} \\
\text { cv. Eagle inoculated with salA mutant BSAL1 } \\
\text { cv. Eagle planted } 3 \text { weeks before sources } \\
\text { cv. Hystyle planted } 3 \text { weeks before sources }\end{array}$ & $\begin{array}{l}6 \mathrm{~m} \text { of bare ground } \\
6 \mathrm{~m} \text { of bare ground } \\
6 \mathrm{~m} \text { of bare ground } \\
6 \mathrm{~m} \text { of bare ground } \\
6 \mathrm{~m} \text { of bare ground } \\
6 \mathrm{~m} \text { of bare ground } \\
6 \mathrm{~m} \text { of bare ground }\end{array}$ & 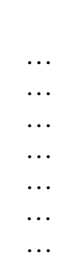 & $\begin{array}{l}+ \\
+ \\
+ \\
+ \\
+ \\
+ \\
+\end{array}$ & $\begin{array}{l}+ \\
+ \\
- \\
\cdots \\
+ \\
+ \\
\ldots\end{array}$ & $\begin{array}{c}\ldots \\
\ldots \\
+ \\
\ldots \\
+ \\
+ \\
\ldots\end{array}$ \\
\hline $\begin{array}{l}\text { Total number of treatments } \\
\text { Number of blocks per treatment }\end{array}$ & & $\begin{array}{l}6 \\
3\end{array}$ & $\begin{array}{l}7 \\
3\end{array}$ & $\begin{array}{l}7 \\
4\end{array}$ & $\begin{array}{l}7 \\
4\end{array}$ \\
\hline
\end{tabular}

a + Indicates treatment included in experiment.

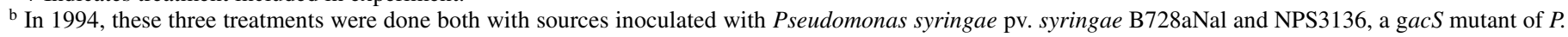
syringae pv. syringae B728a that is known to be less fit in the field than B728a (5).

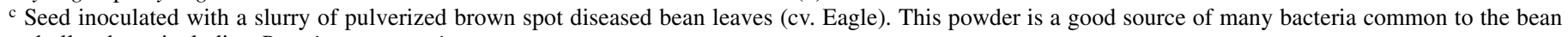
phyllosphere, including $P$. syringae pv. syringae.

d Three additional treatments in 1994 and one additional treatment in each of the 1997 and 1999 experiments are not presented. 
lected at all times from the sinks planted 3 weeks before the sources. For all other treatments, the sampling unit varied as the plants developed. The sampling unit at the first sampling time consisted of cotyledons and emerging primary leaves. The next few samples were individual primary leaves, after which leaflets from trifoliolate leaves were taken from the top of the canopy. All samples were taken randomly within sinks.

Detection and quantitation of spread. To rapidly assess the frequency with which spread occurred while the experiments were ongoing, individual samples collected from the sinks $(n=15$ per sink in 1994, 1998, and 1999 and 17 in 1997) were imprinted on $\mathrm{KB}$ supplemented with rifampicin $(50 \mu \mathrm{g} / \mathrm{ml})(\mathrm{KBR})$ and either nalidixic acid $(50 \mu \mathrm{g} / \mathrm{ml})(\mathrm{KBRNal})$, chloramphenicol $(30 \mu \mathrm{g} / \mathrm{ml})$
(KBRCm), or gentamycin $(2 \mu \mathrm{g} / \mathrm{ml})(\mathrm{KBRGm})$ for B728a* and KBR with kanamycin $(30 \mu \mathrm{g} / \mathrm{ml})$ (KBRKan) for the gacS mutant NPS3136. To minimize fungal growth, cycloheximide $(50 \mu \mathrm{g} / \mathrm{ml})$ and Daconil $2787(50 \mu \mathrm{g} / \mathrm{ml} ; 75 \%$ chlorothalonil active ingredient) were added to all media. Leaf imprinting was done by placing the sample on the surface of the medium. A piece of filter paper (9-cm diameter, Fisher Brand filter paper P8, Fisher Scientific, Chicago) was placed over the sample and gently pressed with a rubber stopper (9-cm diameter). The sample and filter paper were removed after about 4 to $5 \mathrm{~h}$. The plates were scored for the presence or absence of $P$. syringae pv. syringae B728a* (and the gacS mutant NPS3136 in 1994) after 2 to 3 days of incubation at room temperature.
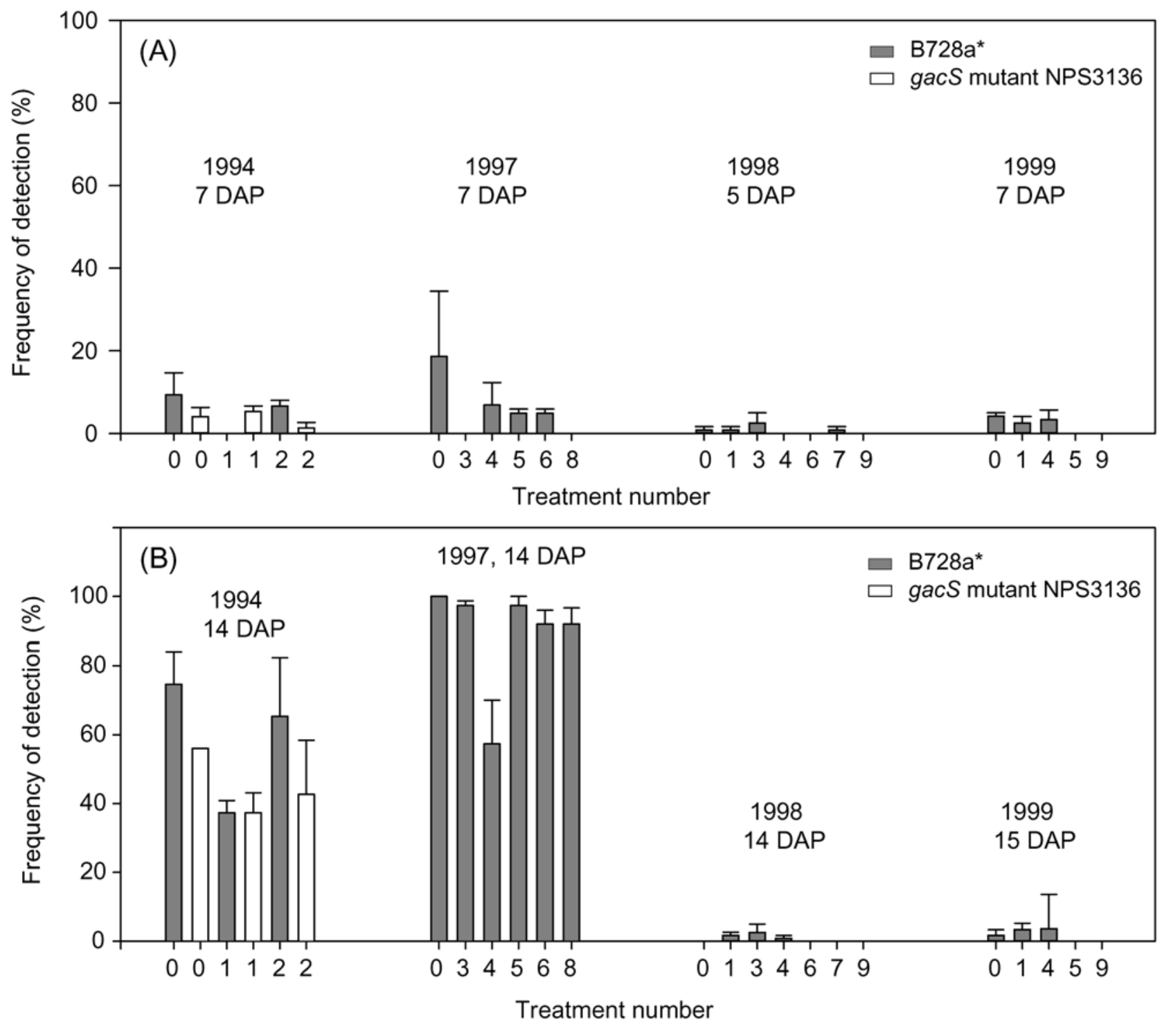

\section{Barrier treatments (cv. Eagle sinks)}

(0) $6 \mathrm{~m}$ bare ground

(1) $6 \mathrm{~m}$ snap bean

(2) $6 \mathrm{~m}$ soybean

(3) $20 \mathrm{~m}$ bare ground

\section{Sink treatments}

(6 $\mathrm{m}$ bare ground barriers)

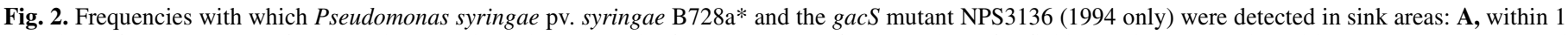

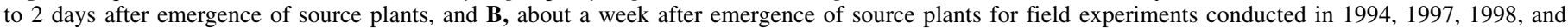

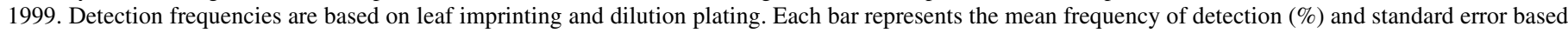

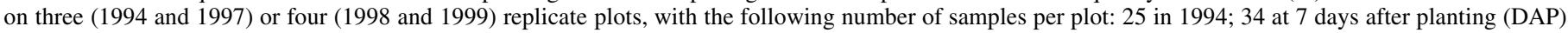
and 25 at 24 DAP in 1997; 30 in 1998; 30 at 7 DAP and 15 at 15 DAP in 1999. 
A second set of samples was collected at random from each sink for enumeration of population sizes of the marked strain by dilution plating (number of samples per sink: 10 in 1994; 17 in 1997; and 15 in 1998 and 1999). Each sample was placed in a test tube $(16 \mathrm{~mm})$ containing $9 \mathrm{ml}$ of sterile phosphate buffer $(0.01 \mathrm{M}$, $\mathrm{pH}$ 7.0). The samples were stored frozen at $-20^{\circ} \mathrm{C}$ for subsequent processing by dilution plating as described previously (4). At the time of processing, the samples were thawed, homogenized, and dilution plated onto KBRNal, KBRCm, or KBRGm for P. syringae pv. syringae B728a*; KBRKan for the gacS mutant NPS3136; and KBRSpc (spectinomycin at $50 \mu \mathrm{g} / \mathrm{ml}$ ) for the salA mutant BSAL1. A semiselective medium for $P$. syringae pv. syringae (medium P of Mohan and Schaad [20]) was used to enumerate population sizes of all $P$. syringae pv. syringae, and $10 \%$ tryptic soy agar (TSA) was used for total culturable bacteria. Cycloheximide $(50 \mu \mathrm{g} / \mathrm{ml})$ was added to the media to prevent fungal growth. In 1997, the actual number of samples processed by dilution plating was initially 17 per sink but decreased to 10 or 8 per sink when population sizes of the marked strain were relatively large on all of the samples. Additional samples were taken from the barriers ( $n=8$ per plot in the 1994 experiment) and from the sources ( $n=5$ per source) for all experiments.

Weather. Parameters of the physical environment were recorded automatically with CR-21X data loggers (Campbell Scientific, Logan, UT). The time of event for accumulation of each millimeter or $0.254 \mathrm{~mm}$ of rainfall was sensed with a Sierra-Misco and TE525 tipping-bucket rain gauges, respectively, and used to determine the volume, duration, and intensity of each rain event. The following parameters were recorded each half hour: air temperature sensed with $75-\mu \mathrm{m}$ evanohm/constantan thermocouples and thermistors, relative humidity with Model HMP35C temperature and relative humidity probe, solar radiation with Li-Cor silicon pyranometers, wind speed and direction with cup anemometers and wind vanes (MET-ONE wind speed and direction sensors and R. M. Young 03001 Wind Sentry unit). All sensors, except the thermocouples, were obtained from Campbell Scientific.

Data analyses. Bacterial counts per individual sample were $\log _{10}$-transformed before calculation of population statistics. Sam-

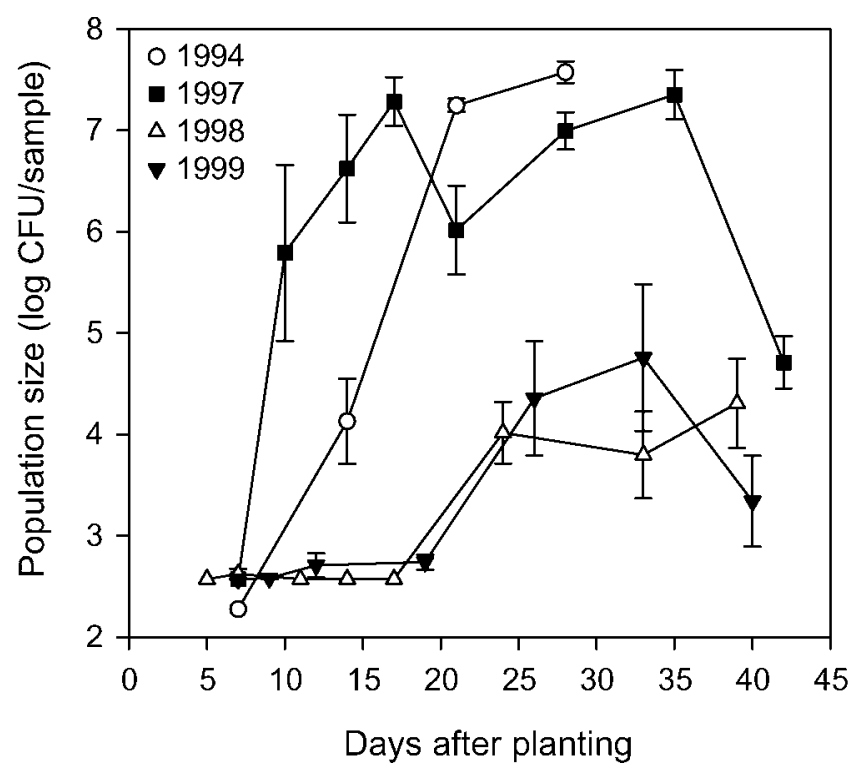

Fig. 3. Spread of Pseudomonas syringae pv. syringae B728a* across $6 \mathrm{~m}$ bare-ground barriers to sinks planted to snap bean cv. Eagle in 1994, 1997, 1998, and 1999 field experiments. Population sizes of $P$. syringae pv. syringae $\mathrm{B} 728 \mathrm{a}^{*}$ in the sink areas were determined by dilution plating. The data are the mean log CFU/sample and standard error based on three (1994 and 1997) or four (1998 and 1999) replicate plots, with the following number of individual samples per plot: 10 in 1994; 17, 10, or 8 in 1997; and 15 in 1998 and 1999. ples with no detectable colonies were assigned the limit of sensitivity of the plating assay (2.57 log CFU per sample). Data management and routine calculations of population statistics were done with Microsoft Excel and MINITAB (Minitab Inc., State College, PA). Treatment effects and treatment-time interactions were determined over all sampling time points within an experiment using repeated measures analysis of variance tests (19) implemented with the Mixed Procedure of SAS (SAS Institute, Cary, NC).

\section{RESULTS}

Population sizes on source plants at emergence. At the time of seedling emergence ( 5 to 7 days after planting [DAP]), mean population sizes of $P$. syringae pv. syringae $\mathrm{B} 728 \mathrm{a}^{*}$ pooled across all of the source plots within an experiment were roughly 5.2 (1994, 9 plots, SE 0.29), 7.0 (1997, 18 plots, SE 0.17), 3.0 (1998, 28 plots, SE 0.08), and 5.9 (1999, 20 plots, SE 0.02) log CFU per sample. The weak source strength in 1998 was likely due to the relatively dry and cloddy soil conditions at the time of planting.

Detection of early spread. $P$. syringae pv. syringae $\mathrm{B} 728 \mathrm{a}^{*}$ (and the gacS mutant NPS3136 in 1994) was consistently detected in sinks by both leaf imprinting and dilution plating within a day or two following emergence of bean seedlings in the sources (Fig. 2A). This was the case even in 1998 when the population sizes of $P$. syringae pv. syringae $\mathrm{B} 728 \mathrm{a}^{*}$ on source plants were quite small (and thus, presumably, source strength was weak). Detection frequencies were usually low and often quite variable among replicate plots for a given treatment at this time. In one extreme case (1997 experiment), detection frequencies were 50, 5.8, and 0\% ( $n=34$ per sink) for replicate cv. Eagle sinks surrounded by 6-m bare-ground barriers. Pooled over all treatments within an experiment, the frequencies with which $P$. syringae pv. syringae $\mathrm{B} 728 \mathrm{a}^{*}$ was detected in the sinks within a day or two after emergence of source plants were 4\% in $1994(n=225), 5.8 \%$ in $1997(n=612)$, $3.8 \%$ in $1998(n=840)$, and $1.5 \%$ in $1999(n=600)$. In five other similar experiments (data not shown), spread was always detected at this time. In one case, $P$. syringae pv. syringae B728a* was detected in sinks a day or two after source plant emergence despite the total lack of rainfall between emergence of any source plants and collection of the first samples (data not shown). There were no consistent trends in detection frequencies within and across experiments to suggest that spread was affected by treatment or fitness of the spreading strain during the first day or two after source plant emergence. Thus, immigration of $P$. syringae pv. syringae $\mathrm{B} 728 \mathrm{a}$ * and the gacS mutant NPS3136 from newly emerged bean plants in the sources to sink areas appeared to occur rapidly regardless of source strength and environmental conditions.

By 14 to 15 DAP (about a week after emergence of source plants), $P$. syringae pv. syringae $\mathrm{B} 728 \mathrm{a}^{*}$ was present at very high frequencies in the sinks in 1994 and 1997 (Fig. 2B). This was also true for NPS3136 in 1994. Detection frequencies, however, remained low at this time in 1998 and 1999. During the first 2 weeks of the experiments, weather conditions (i.e., timely rainfalls) were more favorable for multiplication of $P$. syringae pv. syringae in 1994 and 1997 than in 1998 and 1999. Hence, the higher detection frequencies in 1994 and 1997 compared with 1998 and 1999 were attributed to multiplication of early $P$. syringae pv. syringae B728a* immigrants probably coupled with local (within-sink) dispersal. When weather conditions were not suitable for multiplication of $P$. syringae pv. syringae, B728a* was detected in sinks but the frequency of detection of leaves bearing the marked strain remained low, suggesting that although immigration occurred during such conditions, the lack of subsequent growth limited spread.

Variability in the extent of spread across experiments. Spread of $P$. syringae pv. syringae B728a* to cv. Eagle sinks with 6-m bare-ground barriers was measured in all experiments and 
provided a way to compare experiments conducted under different environmental conditions. Population sizes of $P$. syringae pv. syringae $\mathrm{B} 728 \mathrm{a}$ * in the control sinks increased more rapidly and were larger in 1994 and 1997 than in 1998 and 1999 (Fig. 3). The overall extent of spread based on bacterial population sizes was much greater in 1994 and 1997 than in 1998 and 1999, a pattern similar to that found by examining detection frequencies. Conditions were sufficiently favorable for multiplication of $P$. syringae pv. syringae in 1994 and 1997 that population sizes of the marked strain in the control sinks were similar to those in the sources by roughly 1 (1997) to 2 weeks (1994) after emergence of the source plants.

Effects of altering the barrier on spread. With one exception, altering the nature of the barrier between source and sink areas had no significant effect on population sizes of $P$. syringae $\mathrm{pv}$. syringae B728a* and the less fit gacS mutant NPS3136 in their respective sinks (Figs. 4A, B, and C and 5; Table 2). The one exception was in the 1994 experiment, in which spread of NPS3136 across snap bean barriers was significantly less than across bare ground (Fig. 5E and F; Table 2). Spread of P. syringae pv. syringae B728a* and NPS3136 across snap bean and soybean barriers to their respective sinks was not always significantly different despite the large differences in population sizes of the marked strains that developed on snap bean and soybean plants in the barriers (Fig. 5). Thus, for distances of $6 \mathrm{~m}$, the substrate across which dispersal occurred had little effect on spread, regardless of whether it was highly conducive (snap beans) or unfavorable (soybeans and bare ground) for multiplication of the marked strains.

In 1997, increasing the width of bare-ground barriers from 6 to $20 \mathrm{~m}$ delayed the time at which $P$. syringae pv. syringae $\mathrm{B} 728 \mathrm{a}^{*}$ was first detected in the sinks from roughly 1 to 4 days after emergence of source plants. By 10 DAP in this experiment, population sizes of $P$. syringae pv. syringae $\mathrm{B} 728 \mathrm{a}^{*}$ were approximately $100-$ fold larger in sinks with $6-\mathrm{m}$ barriers than in sinks with $20-\mathrm{m}$ barriers (Fig. 4D). The differences in bacterial population sizes, however, decreased with time. When analyzed over all sampling times (1997 experiment), population sizes of $P$. syringae pv. syringae B728a* in sinks with 6- versus $20-\mathrm{m}$ bare-ground barriers were not significantly different (Fig. 4D; Table 2). In 1998, $P$. syringae pv. syringae $\mathrm{B} 728 \mathrm{a}^{*}$ was detected in sinks with $20-\mathrm{m}$ barriers within a day or two following emergence of plants in the sources (Fig. 2A). Season-long changes in population sizes of the marked strain were not significantly different in sinks surrounded by 6- and 20-m barriers (Fig. 4E; Table 2). Thus, increasing the width of bare-ground barriers from 6 to $20 \mathrm{~m}$ may have delayed spread slightly at times but did not have a season-long impact on spread of $P$. syringae pv. syringae $\mathrm{B} 728 \mathrm{a} *$ from source to sink areas that was large enough to be measured in these experiments.

Effects of altering the nature of the sink on spread. The times at which $P$. syringae pv. syringae B728a* was first detected
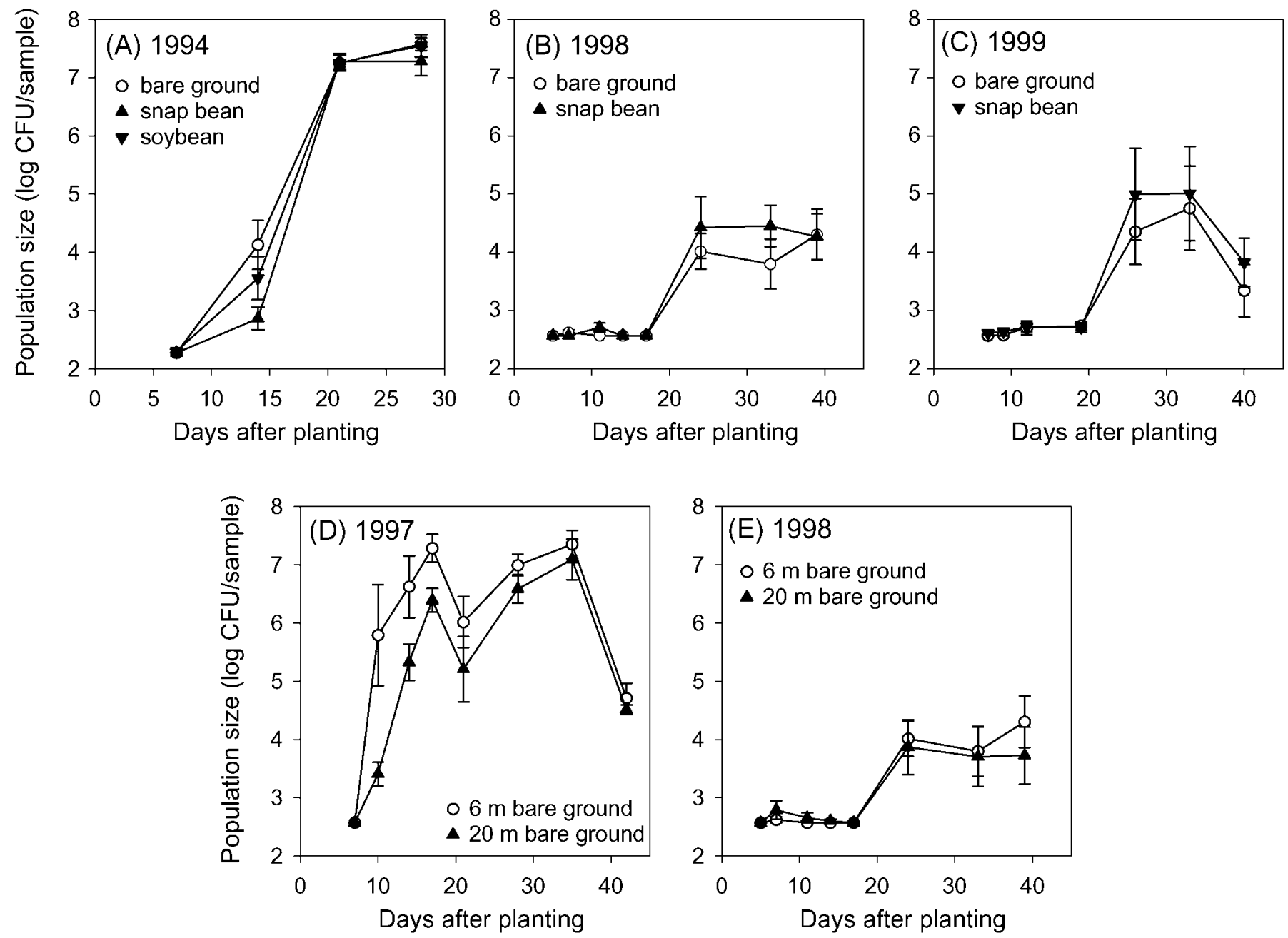

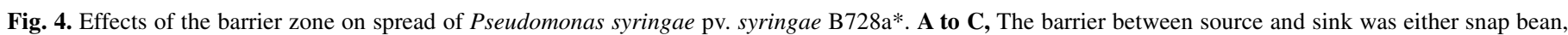

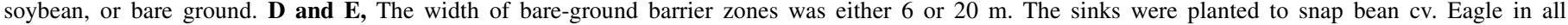

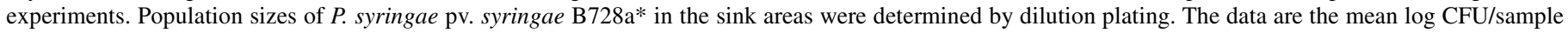

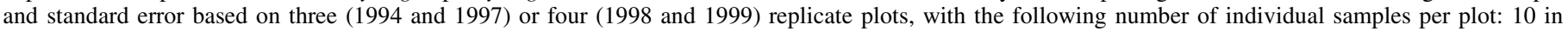
1994; 17, 10, or 8 in 1997; and 15 in 1998 and 1999. 
in sinks planted to cv. Eagle, cv. Hystyle, or soybeans relative to days after planting of the sources were: 1997, 7 DAP for cvs. Eagle and Hystyle; 1998, 5 DAP for cv. Eagle and 7 DAP for cv. Hystyle and soybeans; and 1999, 7 DAP for cv. Eagle and 9 DAP for soybeans (some of the data are presented in Figure 2A). By 14 DAP in 1997, P. syringae pv. syringae B728a* was detected on all (cv. Eagle) or nearly all (cv. Hystyle, 92\%) of the samples from sinks planted to the snap bean cultivars. Thus, early dispersal of $P$. syringae pv. syringae $\mathrm{B} 728 \mathrm{a}^{*}$ was not measurably affected by the nature of the sink. If there were differences in early dispersal, they were too small to be measured in these experiments. In contrast, overall population sizes of $P$. syringae pv. syringae B728a* were significantly larger in sinks planted to cv. Eagle than to cv. Hystyle or soybean (Fig. 6A, B, and C; Table 2). In the 2 years in which soybean sinks were tested, weather conditions were less than optimal for growth of $P$. syringae pv. syringae and little multiplication occurred on either snap bean or soybean. However, even under highly favorable environmental conditions, population sizes of $P$. syringae pv. syringae $\mathrm{B} 728 \mathrm{a}^{*}$ remained small on soybean. This is clearly illustrated by population sizes of the bacterium in association with soybean plants in barrier zones in 1994 (Fig. 5C). In this experiment, the soybeans in the barrier zones were in a sense sinks for spread of $P$. syringae pv. syringae $\mathrm{B} 728 \mathrm{a}$ * from snap beans in the sources and inner "true" sinks once $P$. syringae pv. syringae $\mathrm{B} 728 \mathrm{a}^{*}$ had colonized the latter.

Similar to uninoculated sinks, $P$. syringae pv. syringae B728a* was detected at low frequencies in the inoculated sinks roughly 2 to 7 days after emergence of source plants. However, significantly smaller population sizes of $P$. syringae pv. syringae $\mathrm{B} 728 \mathrm{a} *$ developed on cv. Eagle plants in inoculated sinks than in uninoculated sinks (Fig. 6D and F; Table 2). Population sizes of P. syringae pv.
TABLE 2. Summary of statistical significance of selected pair-wise comparisons of barrier and sink treatments on spread of Pseudomonas syringae pv. syringae $\mathrm{B} 278 \mathrm{a}^{*}$ from repeated measures analyses of variance ${ }^{\mathrm{a}}$

\begin{tabular}{lcc}
\hline Treatment comparisons & Experiment & $P$ value \\
\hline Barrier treatment & & \\
6 m of bare ground vs. 6 m of snap beans & 1994 & 0.2138 \\
& 1994 & $0.0161^{\mathrm{b}}$ \\
& 1998 & 0.3385 \\
6 m of bare ground vs. 6 m of soybeans & 1999 & 0.3277 \\
& 1994 & 0.5343 \\
6 m of bare ground vs. 20 m of bare ground & 1994 & $0.5342^{\mathrm{b}}$ \\
& 1997 & 0.0800 \\
Sink treatment & 1998 & 0.6446 \\
cv. Eagle vs. cv. Hystyle & 1997 & 0.0057 \\
cv. Eagle vs. soybeans & 1998 & 0.0061 \\
cv. Eagle vs. cv. Eagle + mixed phyllosphere & 1998 & 0.0014 \\
bacteria & 1999 & 0.0028 \\
cv. Eagle vs. cv. Eagle + salA mutant BSAL1 & 1997 & 0.0206 \\
cv. Hystyle vs. cv. Hystyle + mixed phyllosphere & 1999 & 0.0030 \\
bacteria & 1997 & 0.0035 \\
cv. Eagle vs. 3-week cv. Eagle & 1997 & 0.1021 \\
& 1998 & 0.0002 \\
cv. Hystyle vs. 3-week cv. Hystyle & 1999 & 0.1896 \\
\hline
\end{tabular}

${ }^{\text {a }} P$ values for overall treatment and treatment-time effects were 0.001 and $<0.0001$ in 1994 with six treatments, three blocks, and four sampling times; 0.0018 and 0.0001 in 1997 with six treatments, three blocks, and eight sampling times; 0.002 and $<0.0001$ in 1998 with seven treatments, four blocks, and eight sampling times; and 0.007 and <0.0001 in 1999 with seven treatments, four blocks, and seven sampling times.

b Sources were inoculated with NPS3136 ( gacS::Tn5); all others were inoculated with $P$. syringae pv. syringae $\mathrm{B} 728 \mathrm{a}^{*}$.
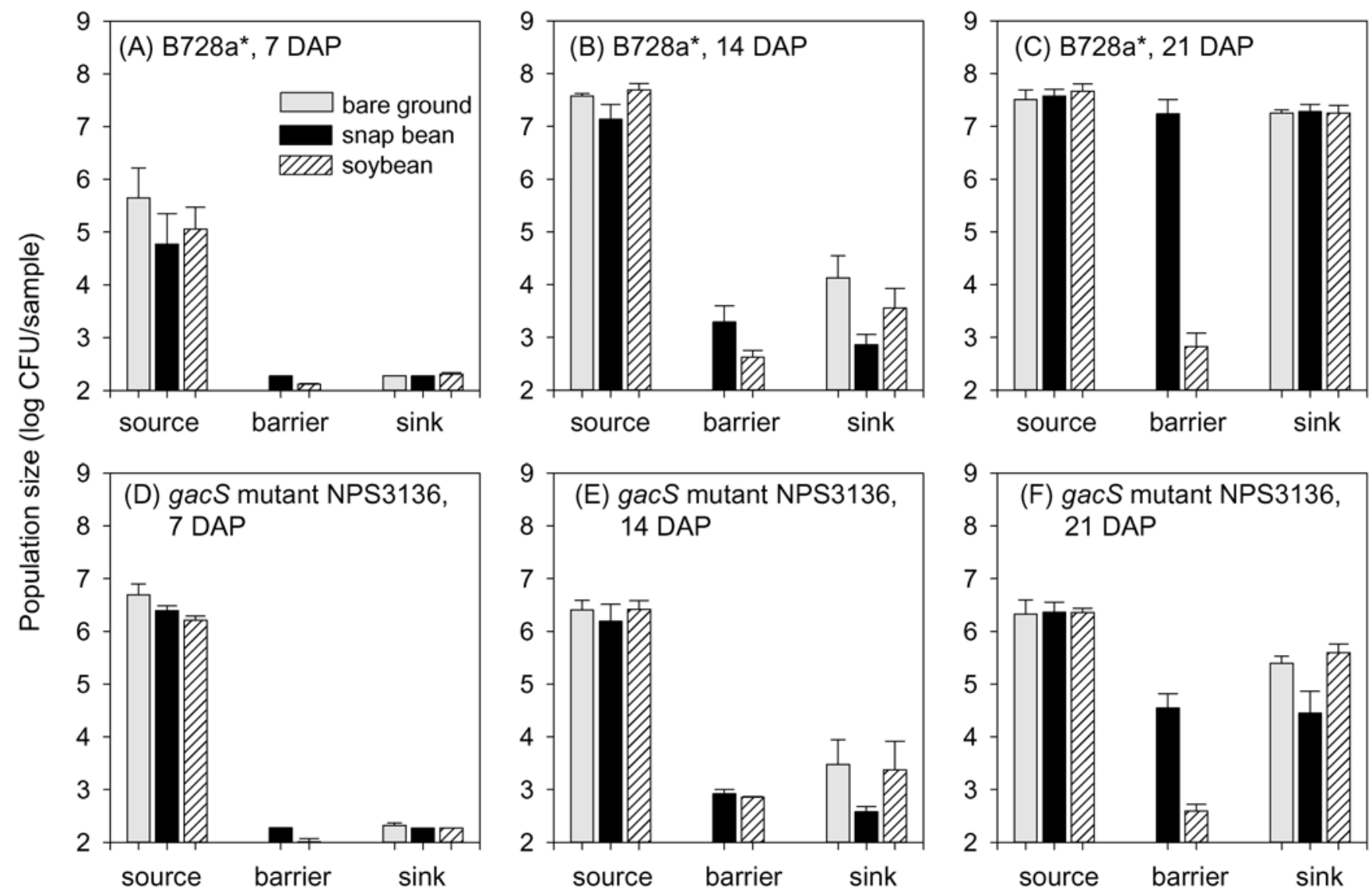

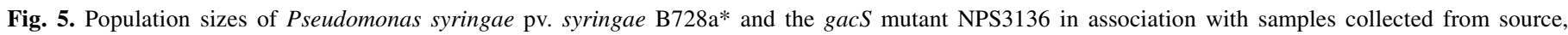

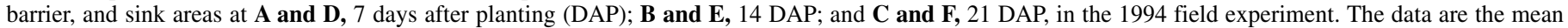
$\log \mathrm{CFU} / \mathrm{sample}$ and standard error based on three replicate plots, with 10 individual samples per plot. 
syringae $\mathrm{B} 728 \mathrm{a}^{*}$ tended to be smaller in sinks planted to inoculated cv. Hystyle than in untreated Hystyle sinks (Fig. 6E). The differences, however, were not statistically significant (Table 2).

The effect of planting the sinks 3 weeks before the sources was variable across experiments (Fig. 6G, H, and I; Table 2). Spread of $P$. syringae pv. syringae B728a* to 3-week cv. Eagle sinks was significantly reduced relative to $\mathrm{cv}$. Eagle sinks planted on the same day or a day before the sources in 1997 (Fig. 6G) and 1998 (Fig. 6H) but not in 1999 (Fig. 6I). In 1998, spread of P. syringae pv. syringae B728a* to cv. Hystyle sinks was similar regardless of when the sinks were planted relative to the sources (Fig. $6 \mathrm{H}$;
Table 2). In both treatments, the extent of spread was minimal and at or nearly at the limit of detection of the plating assay.

Population sizes of $P$. syringae pv. syringae $\mathrm{B} 728 \mathrm{a}^{*}$, total $P$. syringae (i.e., B728a* plus conspecifics based on colony forming units enumerated on $\mathrm{P}$ medium), and total culturable bacteria (enumerated on $10 \%$ TSA) representative of uninoculated, mixed phyllosphere bacteria-inoculated sinks and 3-week cv. Eagle sinks are shown in Figure 7. Total $P$. syringae and B728a* population sizes in the uninoculated cv. Eagle sinks were similar, indicating that the marked strain was the dominant $P$. syringae in these sinks. In contrast, total $P$. syringae population sizes were much larger
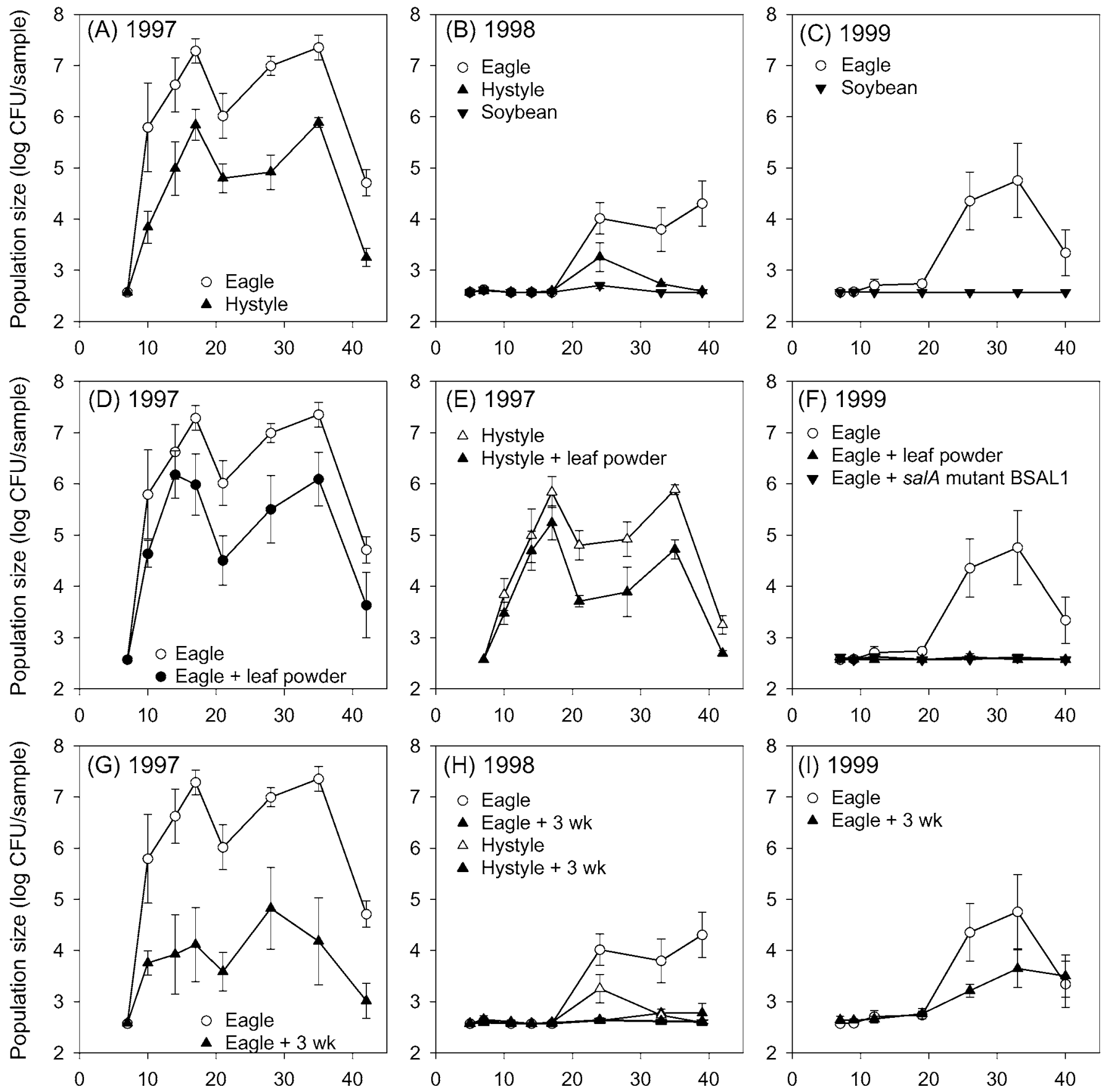

Days after planting

Days after planting

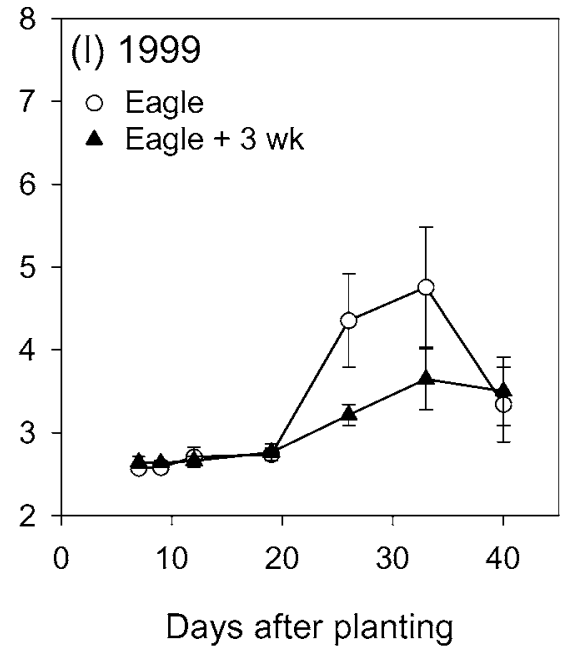

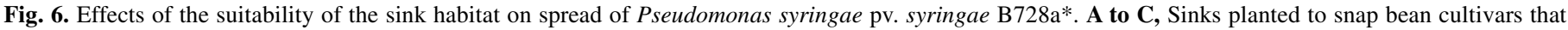

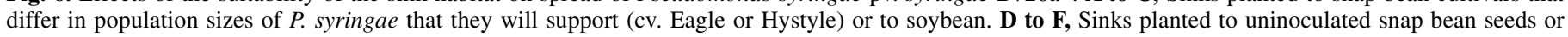

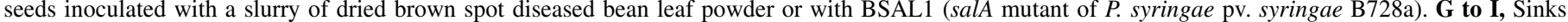

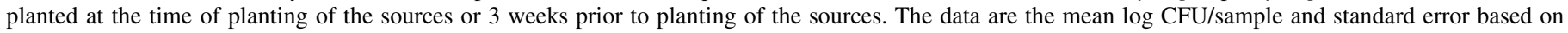

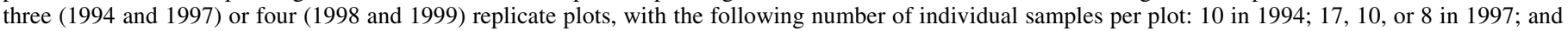
15 in 1998 and 1999. 
than those of B728a* in the mixed phyllosphere bacteria-inoculated and 3-week sinks (Fig. 7B, C, E, and F). Although population sizes of naturally occurring $P$. syringae may not have been the only factor contributing to the reduction in spread of $P$. syringae pv. syringae B728a* to inoculated and 3-week sinks, the presence of large numbers of conspecifics was clearly associated with a decrease in spread of $P$. syringae pv. syringae B728a*.

Taken together, results of the various sink treatments strongly indicate that the suitability of the habitat for multiplication of $P$. syringae strongly influenced spread.

\section{DISCUSSION}

Successful spread requires dispersal of an organism to a new habitat and multiplication on that habitat. Dispersal of $P$. syringae across a barrier $6 \mathrm{~m}$ wide occurred within a day after source plant emergence. In each of nine experiments of this kind (data from four presented here) that we have conducted over six growing seasons, $P$. syringae pv. syringae B728a* was consistently detected at low frequencies in the sinks when samples were first taken.

When conditions were suitable for growth of $P$. syringae pv. syringae, as in the 1994 and 1997 experiments, population sizes of $P$. syringae pv. syringae $\mathrm{B} 728 \mathrm{a}^{*}$ on plants that originated from clean seed (i.e., in sinks of cv. Eagle surrounded by $6 \mathrm{~m}$ of bare ground) were indistinguishable from those on source plants (from seeds inoculated with $P$. syringae pv. syringae $\mathrm{B} 728 \mathrm{a}^{*}$ ) a few weeks after emergence. On this basis, we can conclude that num- bers of bacteria dispersing from source to sink were sufficient to give rise to $P$. syringae pv. syringae population sizes at or near the carrying capacity of the bean leaves within a few weeks under the conditions prevalent during those experiments. Although dispersal may have initially limited the rate at which spread occurred, dispersal could not have limited the final outcome under these conditions.

If dispersal does not limit spread during conditions conducive for growth of $P$. syringae pv. syringae, what is the case during rain-free periods when these bacteria do not grow? Lindow and Anderson (18) suggested that accumulation of immigrants may be sufficient to account for most, if not all, of total culturable bacterial and ice nucleation active bacterial populations on leaves of naval orange in the California Central Valley during the winter. In general, leaves of orange trees are not favorable habitats for growth of bacteria. If we compare frequencies with which $P$. syringae pv. syringae B728a* dispersed to sink leaves 1 and 8 days after source plant emergence in 1998 and 1999, we can rule out simple accumulation of immigrants as an important mechanism for spread of $P$. syringae pv. syringae in the bean phyllosphere. If immigrant accumulation is important, then the frequencies 8 days after source plant emergence should be four to eight times greater than frequencies 1 to 2 days after emergence, assuming a more or less constant immigration rate. In 1998, the frequencies of detection of $P$. syringae pv. syringae $\mathrm{B} 728 \mathrm{a}^{*}$ actually declined between 5 and 14 DAP, and in 1999, the frequencies of detection of $P$. syringae pv. syringae B728a* also declined between 7 and 14 DAP (Fig. 2). Thus, on habitats suitable for multiplication of $P$.
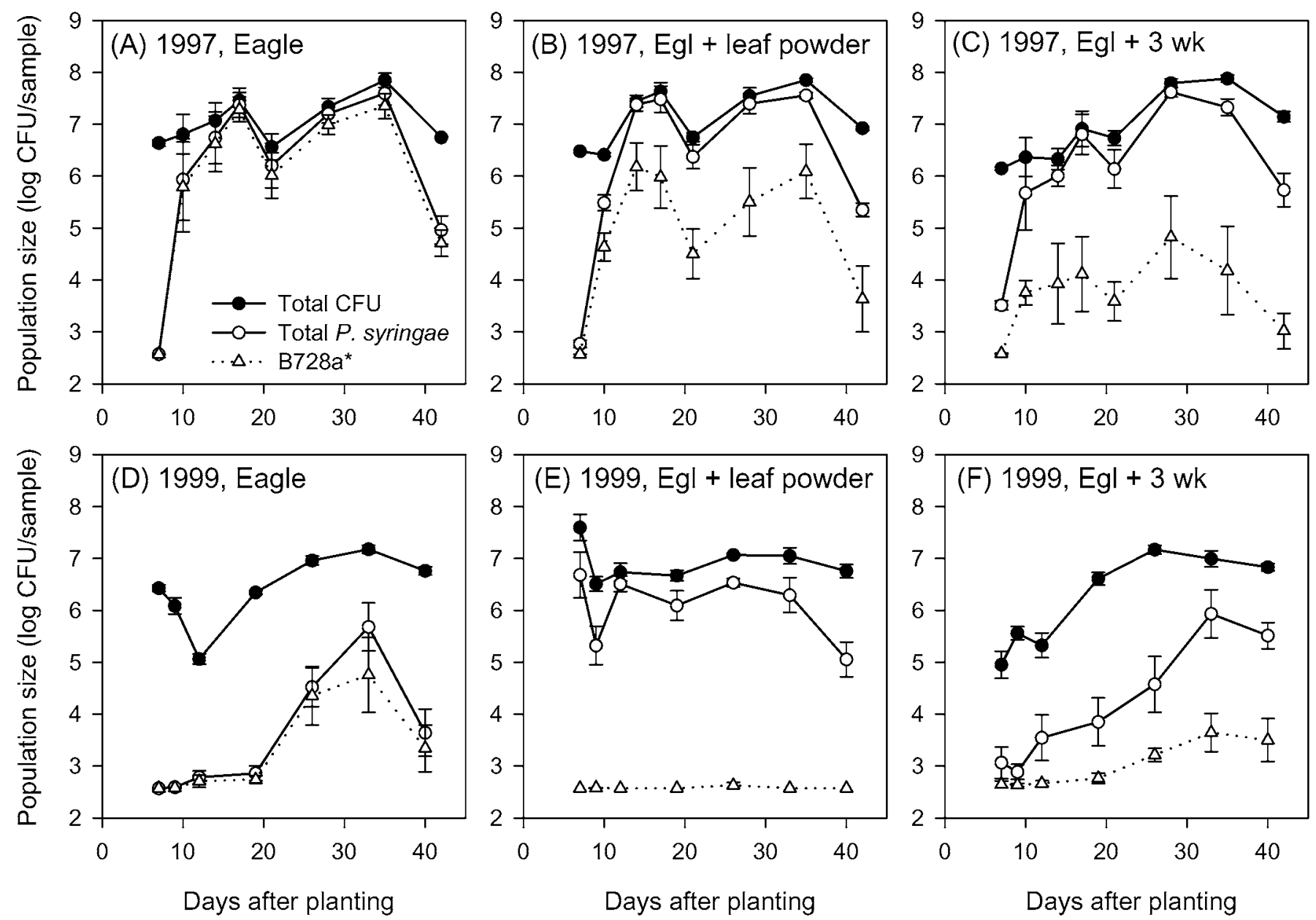

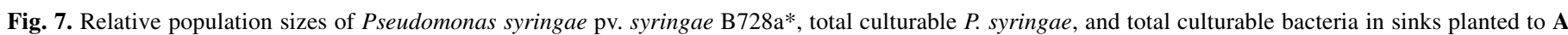

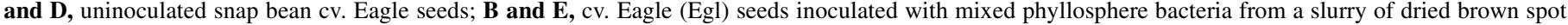

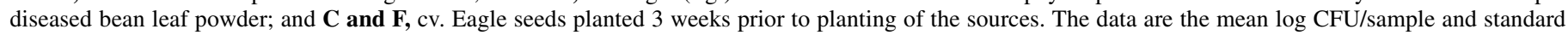

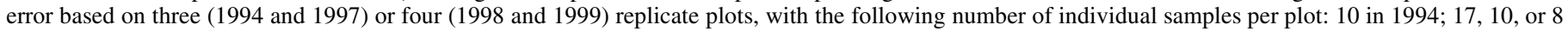
in 1997; and 15 in 1998 and 1999. 
syringae pv. syringae, but under weather conditions not conducive to growth, not only did detectable $P$. syringae pv. syringae $\mathrm{B} 728 \mathrm{a}^{*}$ immigrants not accumulate, but their numbers declined.

Altering the nature of the barrier had no measurable effect on spread of $P$. syringae pv. syringae B728a*. Increasing the distance the bacteria were forced to disperse from 6 to $20 \mathrm{~m}$ may have had a transient effect on spread. At the time the sinks were first sampled, P. syringae pv. syringae $\mathrm{B} 728 \mathrm{a}^{*}$ was detected less frequently in sinks surrounded by $20-\mathrm{m}$ compared with $6-\mathrm{m}$ bare-ground barriers. However, the marked strain was consistently detected at both distances by the next sampling time, usually about 3 days later. Because of the high level of variability associated with the low frequency of detection of dispersal events 1 or 2 days after source plant emergence, our data are relatively insensitive for distinguishing between the possibilities that there may have been an early slowing of the rate of spread across the 20-m (as opposed to $6 \mathrm{~m}$ ) barriers from random variability. Snap bean barriers might have been expected to increase spread by providing an opportunity for the bacteria to spread step-wise across the barrier, and by functioning as a larger, closer source. However, spread across snap bean barriers was not significantly different from that across bare soil or soybean barriers. Because these treatments are compared across experiments done under very different environmental conditions, our conclusions may average trends that differ with conditions. For example, there was a hint (significant difference for the gacS mutant NPS3136 but not for B728a*) that spread across snap bean barriers was decreased relative to spread across bare-ground barriers in the 1994 experiment, when there was rapid growth of $P$. syringae pv. syringae. On the other hand, the trend (also not significant) was exactly the opposite with greater spread across bean barriers than across bare ground in both 1998 and 1999, years with poor conditions for growth of $P$. syringae pv. syringae. Although the only tenable conclusion at this time is that we could identify no barrier effect, there remains the possibility that barrier effects may be real but highly dependent on conditions for growth of the bacteria.

Environmental conditions and suitability of the habitat for bacterial growth had a marked effect on the amount of spread of $P$. syringae pv. syringae B728a*. Comparison of amounts of spread of $P$. syringae pv. syringae $\mathrm{B} 728 \mathrm{a}^{*}$ to $\mathrm{cv}$. Eagle sinks surrounded by $6-\mathrm{m}$ bare-ground barriers across all nine experiments clearly demonstrates that the extent of spread was strongly influenced by environmental conditions that favored growth of $P$. syringae pv. syringae. Further, the treatments that decreased the suitability of the habitat for growth of $P$. syringae pv. syringae B728a* diminished the amount of spread to that habitat. Soybean plants do not support much growth of $P$. syringae pv. syringae, and correspondingly, there was little spread to soybean sinks. Snap bean cv. Eagle plants support more growth of $P$. syringae pv. syringae than cv. Hystyle. There were correspondingly greater amounts of spread of $P$. syringae pv. syringae $\mathrm{B} 728 \mathrm{a}^{*}$ to $\mathrm{cv}$. Eagle sinks than to $\mathrm{cv}$. Hystyle. Increasing numbers of bacteria on leaves of sink plants by either inoculation of seeds with a mixture of phyllosphere bacteria or a single strain (salA mutant BSAL1), or by planting sinks well before the sources (i.e., 3-week sinks) to allow ample time for bacterial colonization, all diminished spread. This is reminiscent of what has been called competitive exclusion (17).

Although source strength at the time of source plant emergence varied by 4 orders of magnitude among the experiments described here, we could identify no consistent effect of source strength on spread. In the 1998 experiment, population sizes of $P$. syringae pv. syringae $\mathrm{B} 728 \mathrm{a}^{*}$ on emerging source plants were unusually low. In general, weather conditions were not optimal for growth of $P$. syringae pv. syringae, and the amount of spread was not particularly different from that of other experiments in which conditions were not suitable for growth (data not shown).

A number of these experiments were done at times when weather conditions were unsuitable for growth of $P$. syringae $\mathrm{pv}$. syringae (e.g., 1998 and 1999 experiments). Early dispersal was detected in these experiments, but lack of subsequent growth limited the amount of successful spread. Our conclusions that there were no significant differences between some treatments in these experiments were probably influenced by the very low numbers of bacteria associated with samples with these treatments. However, our inability to distinguish between no real difference and no measurable differences between these treatments did not influence our overall conclusions.

A question we sought to address with these experiments was the relative roles of dispersal and growth in spread of $P$. syringae pv. syringae in the phyllosphere. The answer is quite clear. Dispersal did not limit spread of $P$. syringae pv. syringae in these experiments. The suitability of conditions for growth of $P$. syringae pv. syringae on the habitat to which the bacteria immigrated had a significant effect on spread of this bacterium. These conclusions of course must be qualified by the limitations of the scale on which the experiments were performed, the sizes of our data sets, and the various caveats associated with comparisons between experiments done at different times and under different conditions.

The amount of bacterial brown spot disease is predictable on the basis of population sizes of $P$. syringae pv. syringae in association with individual leaves $(14,21)$. The results presented here make it quite clear that within-field spread of $P$. syringae pv. syringae is not limited by dispersal of the pathogen but by the suitability of the habitat for growth of the pathogen. If $P$. syringae pv. syringae is present, then epidemics of bacterial brown spot disease should be driven almost completely by the suitability of conditions for multiplication of the pathogen in association with leaves or pods in the field. We find this a compelling explanation of why epidemics of bacterial brown spot most often occur in fields following intense rain storms, events that create conditions favorable for pathogen multiplication.

\section{ACKNOWLEDGMENTS}

This research was supported by the U.S. Department of Agriculture National Research Initiative Competitive Grants Program (Grant 9639210-3690) and the Agricultural Research Service, U.S. Department of Agriculture. We thank L. S. Baker, B. K. Riely, K. D. Fourrier, and the many undergraduate students who assisted with the conduct of these experiments, and the personnel at the University of Wisconsin-Madison Arlington Experiment Station for assistance in field plot preparation.

\section{LITERATURE CITED}

1. Ercolani, G. L., Hagedorn, D. J., Kelman, A., and Rand, R. E. 1974. Epiphytic survival of Pseudomonas syringae on hairy vetch in relation to epidemiology of bacterial brown spot of bean in Wisconsin. Phytopathology 64:1330-1339.

2. Groth, E. M., Hirano, S. S., Baker, L. S., and Upper, C. D. 1995. Insectmediated dispersal of Pseudomonas syringae in a bean field. (Abstr.) Phytopathology 85:1188.

3. Hirano, S. S., Baker, L. S., and Upper, C. D. 1996. Raindrop momentum triggers growth of leaf-associated populations of Pseudomonas syringae on field-grown snap bean plants. Appl. Environ. Microbiol. 62:25602566.

4. Hirano, S. S., Clayton, M. K., and Upper, C. D. 1994. Estimation of and temporal changes in means and variances of populations of Pseudomonas syringae on snap bean leaflets. Phytopathology 84:934-940.

5. Hirano, S. S., Ostertag, E. M., Savage, S. A., Baker, L. S., Willis, D. K., and Upper, C. D. 1997. Contribution of the regulatory gene lemA to field fitness of Pseudomonas syringae pv. syringae. Appl. Environ. Microbiol. 63:4304-4312.

6. Hirano, S. S., Rouse, D. I., Clayton, M. K., and Upper, C. D. 1995. Pseudomonas syringae pv. syringae and bacterial brown spot of snap bean: A study of epiphytic phytopathogenic bacteria and associated disease. Plant Dis. 79:1085-1093.

7. Hirano, S. S., and Upper, C. D. 1983. Ecology and epidemiology of foliar bacterial plant pathogens. Annu. Rev. Phytopathol. 21:243-269.

8. Hirano, S. S., and Upper, C. D. 2000. Bacteria in the leaf ecosystem with emphasis on Pseudomonas syringae-A pathogen, ice nucleus, and epiphyte. Microbiol. Mol. Biol. Rev. 64:624-653. 
9. Hirano, S. S., Willis, D. K., Clayton, M. K., and Upper, C. D. 2001. Use of an intergenic region in Pseudomonas syringae pv. syringae B728a for site-directed genomic marking of bacterial strains for field experiments. Appl. Environ. Microbiol. 67:3735-3738.

10. Hrabak, E. M., and Willis, D. K. 1992. The lemA gene required for pathogenicity of Pseudomonas syringae pv. syringae on bean is a member of a family of two-component regulators. J. Bacteriol. 174:3011-3020.

11. Johnson, K. B., Stockwell, V. O., Burgett, D. M., Sugar, D., and Loper, J. E. 1993. Dispersal of Erwinia amylovora and Pseudomonas fluorescens by honey bees from hives to apple and pear blossoms. Phytopathology 83:478-484.

12. King, E. O., Ward, M. K., and Raney, D. E. 1954. Two simple media for the demonstration of pyocyanin and fluorescin. J. Lab. Clin. Med. 44:301-307.

13. Kitten, T., Kinscherf, T. G., McEvoy, J. L., and Willis, D. K. 1998. A newly-identified regulator is required for virulence and toxin production in Pseudomonas syringae. Mol. Microbiol. 28:917-929.

14. Lindemann, J., Arny, D. C., and Upper, C. D. 1984. Use of an apparent infection threshold population of Pseudomonas syringae to predict incidence and severity of brown spot of bean. Phytopathology 74:1334-1339.

15. Lindemann, J., Constantinidou, H. A., Barchet, W. R., and Upper, C. D. 1982. Plants as sources of airborne bacteria, including ice nucleationactive bacteria. Appl. Environ. Microbiol. 44:1059-1063.
16. Lindemann, J., and Upper, C. D. 1985. Aerial dispersal of epiphytic bacteria over bean plants. Appl. Environ. Microbiol. 50:1229-1232.

17. Lindow, S. E. 1987. Competitive exclusion of epiphytic bacteria by ice Pseudomonas syringae mutants. Appl. Environ. Microbiol. 53:25202527.

18. Lindow, S. E., and Andersen, G. L. 1996. Influence of immigration on epiphytic bacterial populations on navel orange leaves. Appl. Environ. Microbiol. 62:2978-2987.

19. Littell, R. C., Milliken, G. A., Stroup, W. W., and Wolfinger, R. D. 1996. SAS System for Mixed Models. SAS Institute Inc., Cary, NC.

20. Mohan, S. K., and Schaad, N. W. 1987. An improved agar plating assay for detecting Pseudomonas syringae pv. syringae and $P$. s. pv. phaseolicola in contaminated bean seed. Phytopathology 77:1390-1395.

21. Rouse, D. I., Nordheim, E. V., Hirano, S. S., and Upper, C. D. 1985. A model relating the probability of foliar disease incidence to the population frequencies of bacterial plant pathogens. Phytopathology 75:505509.

22. Van der Plank, J. E. 1975. Principles of Plant Infection. Academic Press, New York.

23. Venette, J. R. 1982. How bacteria find their hosts. Pages 3-30 in: Phytopathogenic Prokaryotes. M. S. Mount and G. H. Lacy, eds. Academic Press, New York. 